DOI: https://doi.org/10.24127/ajpm.v10i4.4385

\title{
DEVELOPMENT OF CALCULUS LEARNING MEDIA BASED ON TIMOR ISLAND LOCAL WISDOM WITH SCILAB IMPLEMENTATION
}

\author{
Zulkaidah Nur Ahzan $^{1 *}$, Justin Eduardo Simarmata ${ }^{2}$ \\ ${ }^{1,2}$ Universitas Timor, Kota Kefamenanu, Indonesia \\ *Corresponding author. \\ Email : $\quad$ idhamanieszt@gmail.com ${ }^{\text {*) }}$ \\ justinesimarmata@unimor.ac.id ${ }^{2)}$
}

Received 02 November 2021; Received in revised form 04 December 2021; Accepted 25 December 2021

\begin{abstract}
This study aims to develop learning media for calculus based on the local wisdom of Timor Island with the implementation of Scilab. In addition, the research conducted simulations and compared the conventional methods and Scilab programming language to solve calculus problems. It is crucial to provide knowledge and insight to students to perform various types of simulations related to mathematics using Scilab or other open-source-based programming languages, besides the students become accustomed to solving mathematical problems with the help of programming languages. Twenty-three students of the Department of Mathematics Education in the University of Timor participated in this study to define, design, and develop a learning media in the form of handouts and powerpoints. The subject experts assessed the developed media as "excellent" in the aspect of content and language and "good" for the presentation. Meanwhile, the media experts gave an "excellent" rating for each aspect. Then after the media was tested on students, the media got "excellent" rating for each aspect.
\end{abstract}

Kata kunci:; Calculus; local wisdom; media development; Scilab software.

\begin{abstract}
Abstrak
Penelitian ini bertujuan untuk mengembangkan media pembelajaran kalkulus berbasis kearifan lokal Pulau Timor dengan penerapan Scilab. Selain itu, penelitian ini melakukan simulasi dan membandingkan metode konvensional dan bahasa pemrograman Scilab untuk menyelesaikan masalah kalkulus. Sangat penting untuk memberikan pengetahuan dan wawasan kepada siswa untuk melakukan berbagai jenis simulasi yang berkaitan dengan matematika menggunakan Scilab atau bahasa pemrograman berbasis open source lainnya, selain itu siswa menjadi terbiasa menyelesaikan masalah matematika dengan bantuan bahasa pemrograman. Dua puluh tiga mahasiswa Jurusan Pendidikan Matematika Universitas Timor berpartisipasi dalam penelitian ini untuk mendefinisikan, merancang, dan mengembangkan media pembelajaran berupa handout dan powerpoint. Para ahli mata pelajaran menilai media yang dikembangkan "sangat baik" dalam aspek isi dan bahasa dan "baik" untuk penyajiannya. Sementara itu, ahli media memberikan penilaian "sangat baik" untuk setiap aspek. Kemudian setelah media diujicobakan kepada siswa, media tersebut mendapat rating "sangat baik" untuk setiap aspek.
\end{abstract}

Keywords: Kalkulus; kearifan lokal; pengembangan media; software Scilab.

This is an open access article under the Creative Commons Attribution 4.0 International License

\section{INTRODUCTION}

Learning media in general can be interpreted as a tool in the learning process and can be used to stimulate the thoughts, feelings, skills and abilities of students. Lecturers as instructors have a very important role in choosing learning media to match the material that will be given to students and also as a guide for students to learn it. Therefore, in a learning process, learning media has an important role to facilitate the learning process. 
DOI: https://doi.org/10.24127/ajpm.v10i4.4385

In Permenristekdikti No. 44 concerning National Higher Education Standards (SNPT) contains the legal basis for the application of local wisdom-based learning. Where it is stated that one of the objectives of the SNPT article 3 part a is : "Ensuring the achievement of higher education goals that play a strategic role in educating nation's, advancing science and technology by applying humanities values as well as civilizing and empowering the Indonesian nation that is sustainable". To support the realization of the objective of the SNPT, several studies have been developed such as Ferdianto \& Setiyani (2018), Nurhikmayati \& Sunendar (2020), Normalasarie \& Aulia (2019), Astuti \& Ismadi (2015), Syarifuddin (2018).

Calculus is a branch of mathematics that is essential and can be applied to science, technology, agriculture, economics, and education. Some examples of its applications include: (1) in statistical, physics, and computing calculations; (2) the implementation of mechanical engineering; (3) calculating pest populations; (4) calculating marginal revenue; (5) to increase interest and passion in learning, as well as to increase creativity and communication. These calculus problems can be solved analytically and computationally through both openand closed source programming languages.

Due to its wide implementation, most universities in Indonesia make calculus a compulsory subject in the curriculum. However, the interest of the students is still low as it is considered difficult to understand. This is likely to happen because the teachers have not found the right method in delivering the material to students, and the students might feel bored with the lecture method during the learning process.
Based on a survey, up to $27.59 \%$ of students retook Calculus $\mathrm{I}$ and Calculus II courses in the 2018/2019 and 2019/2020 academic years at the Department of Mathematics Education, University of Timor. Considering the impotance of Calculus for students of the Mathematics Education, student completeness of $72.41 \%$ is not a satisfactory number. Moreover, Calculus is a prerequisite course for several course in Department of Mathematics Education University of Timor. If every academic year the level of completeness does not change or even decreases, it is not impossible that this could be one of the inhibiting factors for students to finish on time. Therefore, this should be a motivation for lecturers to make innovations in learning models for students.

The first solution that can be given is that lecturers can use learning methods or models that follow local cultural conditions. A learning media that fits the concrete situation of the students is expected to stimulate their interest in Calculus. Several studies related to this solution are the creation of animation related to local culture (Wardani \& Endahati, 2019), development of local wisdom-based biology learning modules in the tourist area of Goa Kreo (Lestari, Lianah, \& Hidayat, 2019), and making poetry study teaching materials based on local wisdom with the support of interactive media (Ratnaningsih, 2019). Other studies also prove that mathematics can be delivered based on local wisdom, such as developing teaching materials for students by Ferdianto \& Setiyani (2018), in trigonometry teaching materials (Nurafni et al., 2020), and in pocketbook learning media (Ekayati et. al., 2020). 
DOI: https://doi.org/10.24127/ajpm.v10i4.4385

Several previous studies have shown that the development of teaching materials based on local wisdom can motivate students in lectures, as in the research of Ferdianto \& Setiyani (2018) which shows with the existence of teaching material based on local wisdom, students can relate mathematics to local wisdom and learning. In the research of Ekayati et. al. (2020) also shows that the provision of mathematics learning media based on local wisdom can make students understand the material presented and be more familiar with and remember the local wisdom of West Java. But unfortunately, none of the previous studies have developed Calculus learning media, especially for Integral that based on local wisdom. In fact, considering the importance of Calculus, especially for Integral materials in its implementation in science, technology, economics, and education, media that supports the delivery of materials are needed by lecturers and students.

Next, the second solution is to use the Quantum learning model (Sumargiyani, 2018) or by using webbased learning media (Aditya, 2018). A web-based learning media, especially the open-source Scilab programming language, was used in this study as it does not require a paid license, can be accessed anywhere and anytime, and allows users to control the code that has been created. Several previous studies that used Scilab as a learning medium included determining the solution for electrical circuit analysis using the Cramer method (Anam \& Arnas, 2019), designing a simulation of image formation on a convex mirror (Randjawali, 2017), application of Scilab in circular membrane simulation (Handayani et al., 2018), the introduction of Scilab to vocational students (Supriyadi \& Rustam, 2020), and the use of Scilab in Linear Algebra (Gond \& Pardeshi, 2016). This research is expected to increase students' interest in Calculus and familiarize them with programming languages.

Therefore, based on the previous explanation, it is necessary to develop a learning media for Calculus course based on local wisdom, especially Timor Island, which is implemented with Scilab. So that the purpose of this research is to develop learning media for Integral in Calculus that is based on local wisdom of Timor Island with the implementation of Scilab. Moreover, this study conducted simulations and compared the conventional and learning methods using the open-source Scilab programming language.

\section{METHODS}

\section{Types of research}

Research and Development (R\&D) methods were used in this study. $R \& D$ is a research method used to produce a particular product and to test the effectiveness of the resulting product (Sugiyono, 2015). The overall stages of this method were Define, Design, Development, and Disseminate. However, in this research, it was modified into define, design, and development. Dissemination could be used as an effort to increase the effectiveness of the calculus course. The calculus material could be linked to the local wisdom of Timor Island. The explanation for each stage of this research is as follows:

1. Define

This stage includes the analysis of curriculum, students, learning materials, assignments, and detailed learning objectives. 
2. Design

This stage was carried out through:

a. made Calculus II learning materials following the learning outcomes based on the existing lesson plans;

b. collected references related to local wisdom-based learning media;

c. write the text/manuscript under The Great Dictionary of the Indonesian Language;

d. chose the learning media.

Handouts and PowerPoint (ppt) were selected as the learning media that will contain Integral materials.

3. Development

Validation, improvement, and use of the resulting teaching materials were carried out in this stage. Learning media is categorized as quality if the validators (material experts and media experts) and students provide a minimum assessment of good (Arfinanti, 2018).

\section{Data Analysis}

There were two types of data analysis, namely qualitative data analysis and quantitative data analysis. Qualitative data analysis was data collection, data reduction, data presentation, and conclusions. Meanwhile, quantitative one included material expert validation, media expert validation, and student response questionnaires (Rijali, 2018).

The steps for qualitative data analysis were as follows:

1. Data collection

Information about the use of media and activities carried out by students during lectures was collected. Data collection was carried out by first conducting interviews with several students who had previously programmed Calculus regarding the problems they encountered while attending lectures and asking about the peculiarities of each student's region. After that, collect materials or references related to Integral materials, local wisdom-based media, and the instruments needed in this study such as validation sheets and respon questionnaires.

2. Data reduction

Data reduction aims to summarize the data obtained to focus on the needed information only. Data reduction is done by filtering some of the results obtained at data collection step. For example, after getting the results obtained during the interview, the results are summarized and only the results needed for research are taken. Likewise with Integral materials which will be used as material in making media. The subject matter that became the center of the research was only on Definite Integral and Calculating The Area Under The Curve. While the results obtained from the collection of references related local wisdombased media, are summarized and only taken as needed in this study. Some of the references needed are the development of local wisdombased media, the development of local wisdom-based mathematics media, and the development of local wisdom-based media for students. As for the results obtained regarding the instruments that will be used during the study, only those needed in this study were taken.

3. Data presentation

The data obtained were presented in tabular and a descriptive explanation. Here, the data 
presented in tabular form is data obtained from the results of validation and students respon questionnaires. The validation results of the developed media were obtained from the validation results of media experts and subject experts who were lecturers of the Department of Mathematics Education, each of whom were experts in the field of media and Calculus. While the results of the students response questionnaires were obtained from 23 students who were the subjects of this study.

4. Conclusions

Concluded the data obtained to answer the formulation of the problem in the study. The conclusion was obtained by analyzing the results of the validation of subject experts and media experts as well as student response questionnaires that were adjust to the ideal category of the developed media (see Table 1).

Next, the quantitative data analysis was aimed to gain a specific description of the developed media, such as the following:

\section{Validation by material experts and media experts}

The ideality of the media based on validations of experts and students is presented in Table 1.

Table 1. Categories of ideal media

\begin{tabular}{ccc}
\hline No & $\begin{array}{c}\text { Quantitative Score } \\
\text { Interval }\end{array}$ & Category \\
\hline 1 & $\bar{x}>x_{s}+(S D)_{s}$ & Excellent \\
2 & $x_{s}<\bar{x} \leq x_{s}+(S D)_{s}$ & Good \\
3 & $x_{s}-(S D)_{s}<\bar{x} \leq x_{s}$ & Fair \\
4 & $\bar{x} \leq x_{s}-(S D)_{s}$ & Poor \\
\hline
\end{tabular}

notes:

$\bar{x}:$ average score

$x_{s}$ : ideal score

$(S D)_{s}:$ Ideal Standard Deviation

\section{Research time and subjects}

This research was conducted in March-September 2021 at the Department of Mathematics Education, University of Timor, with 23 students that take the Calculus II course as participants and lecturers who are experts in calculus and learning media as validators.

\section{Research instruments}

The instruments and data collection are considered as the quality parameter of research results (Sugiyono, 2015). This research used a questionnaire and a validation sheet that are presented in Tables 2 to 4 .

Table 2. Validation sheet for material experts

\begin{tabular}{|c|c|}
\hline Aspect & Indicator \\
\hline Contents & $\begin{array}{l}\text { The suitability of the } \\
\text { material with teaching needs } \\
\text { The benefits of the material } \\
\text { for adding insight into } \\
\text { student knowledge } \\
\text { Easy to understand } \\
\text { The factuality of the } \\
\text { substance }\end{array}$ \\
\hline $\begin{array}{l}\text { Presenta- } \\
\text { tion }\end{array}$ & $\begin{array}{l}\text { Motivational speech } \\
\text { Order of presentation } \\
\text { Systematics of the materials } \\
\text { Completeness of the } \\
\text { information }\end{array}$ \\
\hline Delivery & $\begin{array}{l}\text { Legibility } \\
\text { Conformity with Indonesian } \\
\text { grammar rules } \\
\text { Effective and efficient use of } \\
\text { language } \\
\text { Use of communicative } \\
\text { language }\end{array}$ \\
\hline
\end{tabular}


DOI: https://doi.org/10.24127/ajpm.v10i4.4385

Table 3. Validation sheet for media experts

\begin{tabular}{cl}
\hline Aspect & \multicolumn{1}{c}{ Indicator } \\
\hline Contents & $\begin{array}{l}\text { The suitability of the } \\
\text { material with teaching } \\
\text { needs } \\
\text { The benefits of the material } \\
\text { for adding insight into } \\
\text { student knowledge } \\
\text { Easy to understand } \\
\text { The factuality of the } \\
\text { substance } \\
\text { Legibility } \\
\text { Conformity with Indonesian } \\
\text { grammar rules } \\
\text { Effective and efficient use } \\
\text { of language } \\
\text { Use of communicative } \\
\text { language }\end{array}$ \\
\hline
\end{tabular}

Table 4. Questionnaire for students

\begin{tabular}{|c|c|}
\hline Aspect & Indicator \\
\hline Con & $\begin{array}{l}\text { The material presented in a } \\
\text { sequenced and interesting } \\
\text { way to understand } \\
\text { The media is able to increase } \\
\text { the intensity of learning to be } \\
\text { more independent } \\
\text { The media is able to increase } \\
\text { learning motivation } \\
\text { The media can be used } \\
\text { anytime and anywhere }\end{array}$ \\
\hline Delivery & $\begin{array}{l}\text { Text used on media } \\
\text { The simplicity of the } \\
\text { language used } \\
\text { Easy to understand } \\
\text { Additional knowledge } \\
\text { presented in the media } \\
\text { glossary/references }\end{array}$ \\
\hline
\end{tabular}

A validation sheet was given during the evaluation to know the feasibility of the developed media, while the questionnaire was handed after the media was applied in the course to find out whether the developed media attracted student motivation in learning.

\section{RESULTS AND DISCUSSION}

The result of the developed media can be seen in Figure 1 until Figure 5.

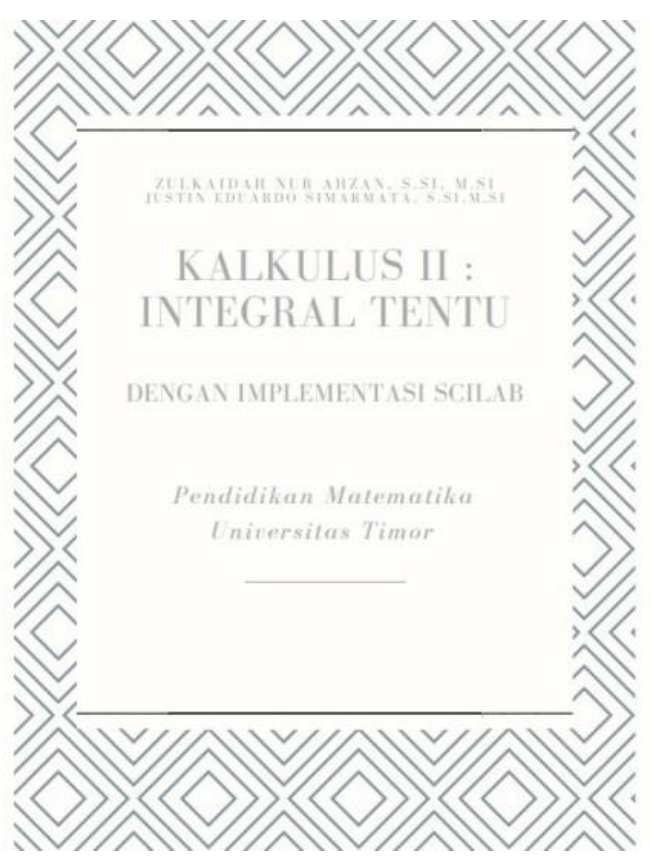

Figure 1. Handout cover

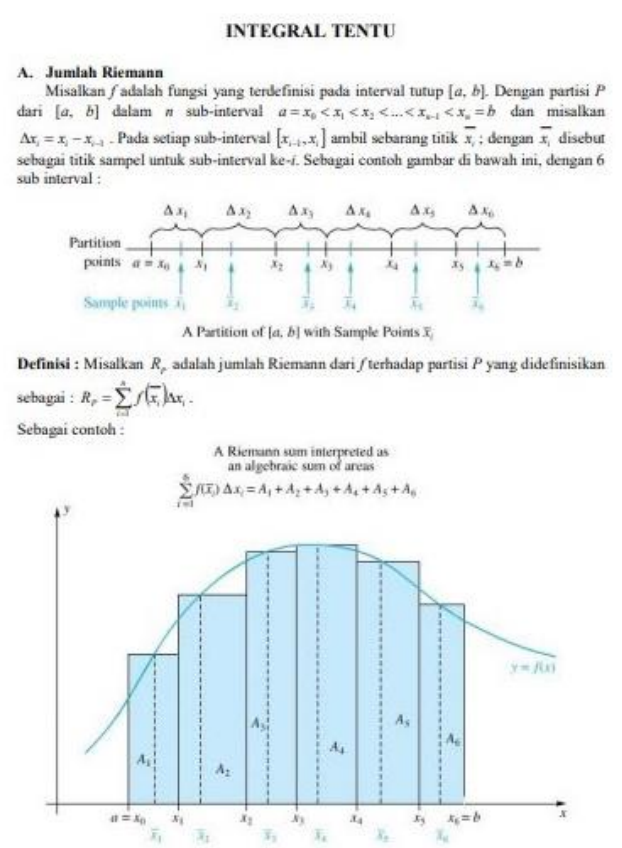

Figure 2. Handout content 
DOI: https://doi.org/10.24127/ajpm.v10i4.4385

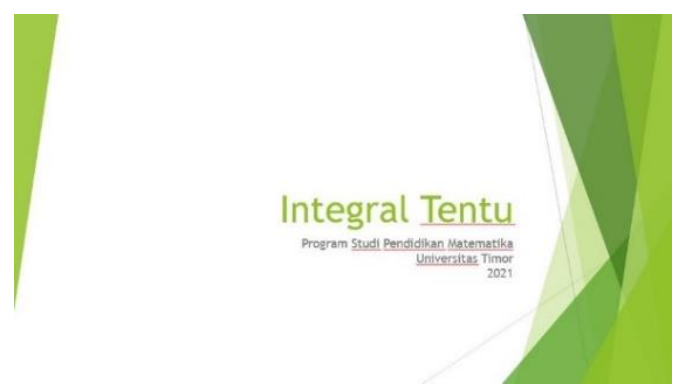

Figure 3. PowerPoint cover

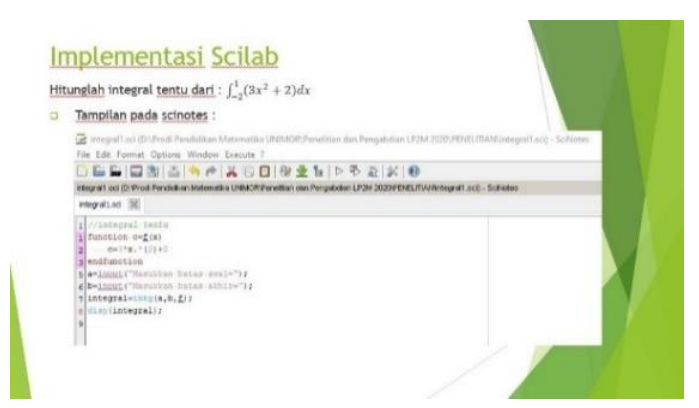

Figure 4. PowerPoint content (1)

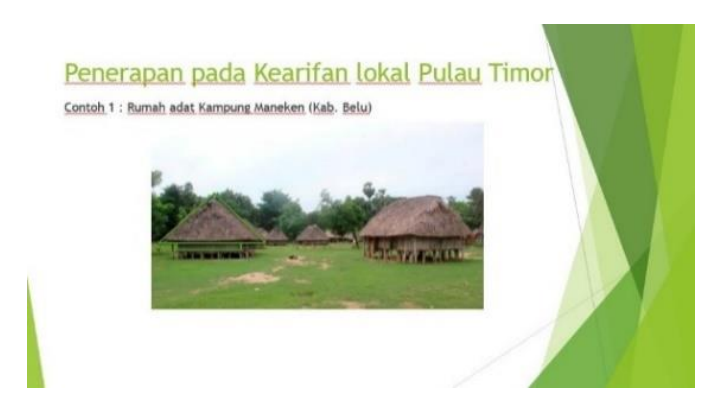

Figure 5. PowerPoint content (2)

This study found a difference in the assessment of the presentation aspect between material experts and student responses. A more detailed explanation of the findings is described below.

1. Define

The result of the define stage is to analyze the curriculum in the
2021/2022 academic year. Calculus will be programmed by third semester students and above, with a total credit of 3 credits (Semester Credit System).

2. Design

The results of the design stage are as shown in Figure 1-5.

\section{Media eligibility based on material expert assessment}

The material expert validators in this study were two lecturers who had expertise in Calculus. The media developed received an "excellent" rating in content and delivery aspects, with an ideal level of $81.25 \%$ and $90.63 \%$, respectively. Meanwhile, the presentation aspect received a "good" rating with an ideal level of 75\% (Table 5). The results obtained from the presentation aspect got a "good" rating from material experts because the exercises presented in the media are still lacking. The lack of exercises in this media due to the limited time of the study, the peculiarities of the regions taken in this study are only limited to North Central Timor Regency, Belu Regency, and South Central Timor Regency and also the limited number of tools, in this case laptops or PCs, which is required in this study. The number of students in this study were 23 students, but less than 5 students had laptops.

Table 5. Validation results by material experts

\begin{tabular}{ccccc}
\hline Validator & Contents & Presentation & Delivery & Total \\
\hline Validator I & 13 & 12 & 15 & 40 \\
Validator II & 13 & 12 & 14 & 39 \\
\hline Total & $\mathbf{2 6}$ & $\mathbf{2 4}$ & $\mathbf{2 9}$ & $\mathbf{7 9}$ \\
\hline Average & $\mathbf{1 3}$ & $\mathbf{1 2}$ & $\mathbf{1 4 . 5}$ & $\mathbf{3 9 . 5}$ \\
\hline Ideal Level & $\mathbf{8 1 . 2 5}$ & $\mathbf{7 5}$ & $\mathbf{9 0 . 6 3}$ & $\mathbf{8 2 . 2 9}$ \\
\hline Category of Ideal & Excellent & Good & Excellent & Excellent \\
\hline
\end{tabular}




\section{Media eligibility based on media expert assessment}

The media experts were two lecturers who have expertise in the development of learning media. The developed media received an "excellent" rating with an ideal percentage of $96.875 \%$ for each aspect of the assessment (Table 6). After being modified based on suggestions from the validators, the media was then tested on students.

Table 6 . Validation results by media experts

\begin{tabular}{lccc}
\hline \multirow{2}{*}{ Validator } & \multicolumn{2}{c}{ Aspect } & \multirow{2}{*}{ Total Score } \\
\cline { 2 - 3 } & Contents & Delivery & \\
\hline Validator 1 & 16 & 16 & 32 \\
Validator 2 & 15 & 15 & 30 \\
\hline Total Score & $\mathbf{3 1}$ & $\mathbf{3 1}$ & $\mathbf{6 2}$ \\
\hline Average Score & $\mathbf{1 5 , 5}$ & $\mathbf{1 5 , 5}$ & $\mathbf{3 1}$ \\
\hline Ideal Level & $\mathbf{9 6 , 8 7 5}$ & $\mathbf{9 6 , 8 7 5}$ & $\mathbf{9 6 , 8 7 5}$ \\
\hline Category of Ideal & Excellent & Excellent & Excellent \\
\hline
\end{tabular}

Student Response To The Developed Media

Table 7. Questionnaire results

\begin{tabular}{cccc}
\hline $\begin{array}{c}\text { Student } \\
\text { Initials }\end{array}$ & Contents & Delivery & Total \\
\hline DT & 15 & 12 & 27 \\
EK & 12 & 14 & 26 \\
MLS & 16 & 16 & 32 \\
MFL & 16 & 16 & 32 \\
AM & 14 & 12 & 26 \\
FKT & 14 & 13 & 27 \\
YB & 13 & 9 & 22 \\
RCE & 14 & 13 & 27 \\
MYN & 10 & 12 & 22 \\
MS & 11 & 12 & 23 \\
VGT & 13 & 14 & 27 \\
FO & 14 & 13 & 27 \\
RB & 16 & 16 & 32 \\
MKN & 10 & 12 & 22 \\
MOU & 13 & 13 & 26 \\
APT & 16 & 16 & 32 \\
RYN & 12 & 9 & 21 \\
MHY & 12 & 13 & 25 \\
YM & 13 & 15 & 28 \\
OU & 14 & 12 & 26 \\
MSL & 14 & 14 & 28 \\
AM & 15 & 14 & 29 \\
AMB & 15 & 15 & 30 \\
\hline Total & $\mathbf{3 1 2}$ & $\mathbf{3 0 5}$ & $\mathbf{6 1 7}$ \\
\hline Average & $\mathbf{1 3 . 5 7}$ & $\mathbf{1 3 . 2 6}$ & $\mathbf{2 6 . 8 3}$ \\
\hline Ideal & $\mathbf{8 4 . 7 8}$ & $\mathbf{8 2 . 8 8}$ & $\mathbf{8 3 . 8 3}$ \\
Level & & & \\
\hline Category & Excellent & Excellent & Excellent \\
of Ideal & & & \\
\hline & & & \\
\hline
\end{tabular}

The media that had been scored by validators was then implemented and assessed by students through the questionnaire. The results of the student response are provided in Table 7.

The developed media obtained an "excellent" appraisal from students in both aspects with the ideal percentage of $84.78 \%$ and $82.88 \%$, respectively (Table 7). Some considerations in developing media in the form of handouts and PowerPoints are:

1. Handouts can give students more time to understand the material. Previously, most of the lecture time was used to record material. The handout could be used by students to understand and explore the ability to use Scilab during the class.

2. PowerPoints were used to convey material that is more organized and structured.

Based on the results obtained from media validation from material experts and media experts as well as responses from students, the media developed is feasible to be implemented for students of the Unimor Mathematics 
Education Department who program Calculus. This is because the developed media are adapted to the concrete situations of the students from Timor Island and also the media developed not only require theoretical but also practical skills. So that students become motivated in learning activities. This research is in line with research conducted by Arfinanti (2018) which also states in the result of her research that media that has feasibility in its development and is in accordance with student needs not only theoretically but also practically can produce media that makes students motivated in learning process. This result was also supported by several previous studies, such as the study conducted by (Nurrita, 2018), (Ardhiyah \& Radia, 2020) regarding adobe flash-based media on fractional material, and Amin \& Mayasari (2015) on android applications to improve learning outcomes. Therefore, the learning media is very decisive in developing the potential that exists in students as learning subjects. By suitable media, students can improve their academic quality and increase their scores in courses.

\section{CONCLUSION AND SUGGESTION}

The conclusions of this research is the learning media developed in this study was a media that combines the typical culture of the people of Timor Island and a Scilab numerical device for Integral in Calculus. The media are in the form of handouts and PowerPoints.

It is expected that the media developed in this study is not only for Calculus courses. Thus, it will be very necessary to develop a media for other courses to increase the motivation of students in undergoing lectures, especially for Mathematics Education Program, the University of Timor.

\section{ACKNOWLEDGEMENTS}

The authors would like to thank the Research and Community Service Institute (LPPM) of the University of Timor for funding this research (contract number 57/UN60/LPPM/PP/2021).

\section{REFERENCES}

Aditya, P. T. (2018). Pengembangan Media Pembelajaran Matematika Berbasis Web Pada Materi Lingkaran Bagi Siswa Kelas Viii. Jurnal Matematika Statistika Dan Komputasi, $15(1), \quad 64$. https://doi.org/10.20956/jmsk.v15 i1. 4425

Amin, A. K., \& Mayasari, N. (2015). Pengembangan Media Pembelajaran Berbentuk Aplikasi Android Berbasis Weblog Pendidikan Matematika Ikip Pgri Bojonegoro. Journal Magistra, 27(94), 12-23.

Anam, K., \& Arnas, Y. (2019). Metoda Cramer Untuk Solusi Analisa Rangkaian Listrik Menggunakan Scilab. Jurnal Ilmiah Aviasi Langit Biru, 12(1), 61-68.

Ardhiyah, M. A., \& Radia, E. H. (2020). Pengembangan Media Berbasis Adobe Flash Materi Pecahan Matematika Untuk Meningkatkan Hasil Belajar. Jurnal Penelitian Dan Pengembangan Pendidikan, 4(3), 479.

https://doi.org/10.23887/jppp.v4i3 .28258

Arfinanti, N. (2018). Pengembangan Media Pembelajaran Matakuliah Metode Numerik dengan Implementasi Scilab Berbantuan Software Latex. Al-Khwarizmi: Jurnal Pendidikan Matematika Dan Ilmu Pengetahuan Alam, 6(2), 121-138. 
https://doi.org/10.24256/jpmipa.v $6 \mathrm{i} 2.370$

Astuti, E. P., \& Ismadi, -. (2015). Pengembangan Bahan Ajar Mata Kuliah Dasar-Dasar Desain Berbasis Kearifan Lokal Bagi Mahasiswa Pendidikan Seni Rupa. Imaji, 11(2). https://doi.org/10.21831/imaji.v11 i2.3838

Ekayati, D.A.Y.,Karim, A., \& Wiratomo, Y. (2020). Pengembangan Media Pembelajaran Pocket Book Berbasis Kearifan Lokal pada Pelajaran Matematika SMP Kelas VII. Prosiding Seminar Nasional Dan Diskusi Panel Pendidikan Matematika Universitas Indraprasta PGRI, 263-272.

Ferdianto, F., \& Setiyani, S. (2018). Pengembangan Bahan Ajar Media Pembelajaran Berbasis Kearifan Lokal Mahasiswa Pendidikan Matematika. JNPM (Jurnal Nasional Pendidikan Matematika), 2(1), 37. https://doi.org/10.33603/jnpm.v2i 1.781

Gond, S., \& Pardeshi, S. (2016). Use OF Scilab In Linear Algebra. International Engineering Journal For Research \& Development, 2(5), 1-6.

Handayani, D. N. S., Pramudya, Y., Suparwoto, S., \& Muchlas, M. (2018). The Application of Scilab Software in Frequency Mode Simulation on the Circular Membrane. Journal of Physics: Theories and Applications, 2(2), 83.

https://doi.org/10.20961/jphystheo r-appl.v2i2.31274

Lestari, A. W. (2019). Pengembangan Modul Pembelajaran Biologi Berbasis Kearifan Lokal Di
Kawasan Wisata Goa Kreo Pada Materi Ekosistem Kelas X. Phenomenon, 09(1), 1-9. https://journal.walisongo.ac.id/ind ex.php/Phenomenon/article/view/ 3113/2119

Normalasarie, \& Aulia, S. (2019). Pengembangan Media Pembelajaran Ilmu Sosial Budaya Berbasis Kearifan Lokal (Kain Sasirangan Khas Kalimantan). Elementa: Jurnal Prodi Pgsd Stkip Pgri Banjarmasin, 1(1), 6170.

Nurafni, A., Pujiastuti, H., \& Mutaqin, A. (2020). Pengembangan Bahan Ajar Trigonometri Berbasis Kearifan Lokal. Journal of Medives: Journal of Mathematics Education IKIP Veteran Semarang, $4(1), \quad 71$. https://doi.org/10.31331/medivesv eteran.v4i1.978

Nurhikmayati, I., \& Sunendar, A. (2020). Pengembangan Project Based Learning Berbasis Kearifan Lokal Berorientasi pada Kemampuan Berpikir Kreatif dan Kemandirian Belajar. Mosharafa : Jurnal Pendidikan Matematika, 9(1), 1-12.

Nurrita, T. (2018). Pengembangan Media Pembelajaran Untuk Meningkatkan Hasil Belajar Siswa. Mysikat, 03(01), 171-187.

Randjawali, E. (2017). Desain Simulasi Pembentukan Bayangan Pada Cermin Cembung Menggunakan Gui Builder Scilab 5.5.0. Jurnal Penelitian Fisika Dan Aplikasinya (JPFA), $\quad 7(2), \quad 102$. https://doi.org/10.26740/jpfa.v7n2 .p102-114

Ratnaningsih, D. (2019). Bahan Ajar Kajian Puisi Berbasis Kearifan Lokal (Piil Pesenggiri) Dengan Dukungan Media Interaktif Prezi 
DOI: https://doi.org/10.24127/ajpm.v10i4.4385

Presentation. Edukasi Lingua

Sastra, 17(2), 27-34.

Rijali, A. (2019). Analisis Data

Kualitatif (Qualitative Data

Analysis). Alhadharah: Jurnal Ilmu Dakwah, 17(33), 81.

Sugiyono. (2015). Metode penelitian pendidikan (pendekatan kuantitatif kualitatif dan $r \& d$. 456.

Sumargiyani. (2018). Peningkatan Motivasi Belajar Mahasiswa Pendidikan Matematika Pada Mata Kuliah Kalkulus Diferensial Menggunakan Model Pembelajaran Quantum. Prosiding Seminar Nasional Matematika, 155-161.

Supriyadi, E., \& Rustam, A. H. (2020). Pengenalan komputasi matematika scilab kepada siswa sekolah menengah Kejuruan. Jurnal Analisa, 6(2), 173-186. https://doi.org/10.15575/ja.v6i2.9 811

Syarifuddin, S. (2018). Penerapan Model Pembelajaran Saintifik Approacd Berbasis Media Pembelajaran Kearifan Lokal pada Mata Kuliah Dasar-Dasar Sosiologi dalam Membangun Karakter dan Meningkatkan Hasil Belajar Mahasiswa Pendidikan Sosiologi Universitas Muhammadiyah Makassar. Jurnal Etika Demokrasi, 3(2), 75-85.

Wardani, S., \& Endahati, N. (2019). Animasi Media Pembelajaran Bermuatan Kearifan Lokal. Seri Prosiding Seminar Nasional Dinamika Informatika Universitas PGRI Yogyakarta, 68-73. 